\title{
EFFECT OF SURFACE IRRIGATION METHODS AND LAND LEVELING ON SALT DISTRIBUTION AND MOISTURE UPTAKE BY COTTON PLANT IN SALT AFFECTED SOILS AT NORTH DELTA \\ Sonbol, H. A. ${ }^{*}$; E.M. El Hadidi*; M.M. Saied ${ }^{\star *}$ and M.A. El-F, Aiad ${ }^{\star *}$ \\ * Soils Dept., Fac. of Agric., Mansoura Univ. \\ ** Soils, Water and Environment Res. Inst.
}

\begin{abstract}
Two field trials were conduced at Sakha Agricultural Research Station during the two successive growing seasons 2004 and 2005 to study the impact of three methods of surface irrigation which are: 1- Short Furrows, 2. Long furrows and 3. Border irrigation, and three land leveling practices were used as, traditional land leveling, dead level (precision leveling) and ground surface slope of $10 \mathrm{~cm} / 100 \mathrm{~m}(0.1 \%)$ on salt distribution patterns and moisture extraction under Egyptian cotton variety Giza 86. The experimental design which used in this study was split-plot with four replicates, where the main plots were assigned to surface irrigation methods and the sub plot were devoted to land leveling methods.

Results revealed that, the salt concentration in soil after fifth irrigation was decreased by $17.79,15.22$ and $12.76 \%$ under border, long furrows and short furrows. While the decrease in salt concentration after harvesting of cotton were $20.17,20.12$ and $13.71 \%$ under border, long furrows and short furrows irrigation. Furthermore, the salt content under $0.1 \%$ ground surface slope was decreased as compared to dead level and traditional land leveling. At the same time, more than $70 \%$ of water absorbed by cotton roots was obtained from the upper $30 \mathrm{~cm}$ soil layer, while less than $30 \%$ was extracted from the lower soil layer $(30-60 \mathrm{~cm})$.
\end{abstract}

\section{INTRODUCTION}

Management of irrigation water and improving soil productivity in Egypt became necessary in order to face water shortage as well as increasing population.

Irrigation is generally defined as the application of water to soil for the purpose of supplying the essential moisture for plant growth.

The salt content under furrow irrigation system generally increased by increasing distance from the furrow and with the depth, the giving a decrease in salt content with $25.45 \%$ of the amount before irrigation. This indicates the effect of applied water in leaching soluble salts deep down the soil profile (Abd El-Razek et al., 1992). It has been noticed that $0.1 \%$ ground surface slope treatment achieved the highest production and received less amount of water delivered to the crops. The highest values of both water use and water utilization efficiencies, the highest values of application efficiency and the highest of leaching efficiency of salts, were achieved under $0.1 \%$ slope, while the traditional methods recorded the lowest one and used the highest values of irrigation water (El-Mowelhi et al., 1995). Precision land leveling as well was efficient drainage system is the most important factor in 
soil and water management effect on rate and uniformity of salt leaching (Abo Soliman et al., 1996). The precision land leveling using LASER scraper leached considerable amount of soluble salts from salt affected soil in North Delta compared to traditional leveling (El-Mowelhi et al., 1999). The soil salinity increased by increasing soil depth after irrigation but before the next irrigation, the soil salinity decreased by increasing depth under furrow irrigation system (Helmy et al., 2000). The highest percentage of the moisture uptake by cotton plant roots is occurred in the soil surface $15 \mathrm{~cm}$ depth, it ranges between 43.49 and $45.06 \%$. While the less water is extracted from the successive depths (Meleha, 2000). The highest uptake of water by cotton plants was occurred with irrigation of all furrows under precision land leveling for both seasons, while the lowest uptake of water was obtained with alternative furrow irrigation under traditional land leveling (El-Shahawy, 2004).

\section{MATERIALS AND METHODS}

Two field experiments were conduced at Sakha Agricultural Research Station during 2004 and 2005 summer seasons using Egyptian cotton (Gossypium barnadense L.), variety Giza 86).

The soils of two experimental sites were clayey in texture and saline. Some chemical and hydrological parameters of soils are shown in Table (1). Mechanical analysis was carried out using the pipette method (Dewis and Fertias 1970). Bulk density was determined by using paraffin wax method (Dewis and Fertias, 1970). Soil reaction $(\mathrm{pH})$ was measured in (1: 2.5 soil suspension) using combined electrode $\mathrm{pH}$ meter as mentioned by (Richards 1954). Soil salinity was determined by measuring the electrical conductivity in the extract of saturated soil paste in $\mathrm{dSm}^{-1}$ as explained by (Jackson (1967). The amounts of water soluble cations $\left(\mathrm{Ca}^{++}, \mathrm{M}^{\mathrm{g}++}, \mathrm{Na}^{+}\right.$and $\left.\mathrm{K}^{+}\right)$and anions $\left(\mathrm{CO}_{3}, \mathrm{HCO}_{3}, \mathrm{Cl}^{-}\right.$and $\left.\left.\mathrm{SO}_{4}\right)\right)$ were determined in the extract of saturated soil paste by the methods described by (Hessse 1971). Field capacity and permanent wilting point were calculated from the soil moisture characteristic curve (PF) according to (Black, 1965) and available water value is the difference between field capacity and permanent wilting point.

The experimental design was split plot with four replicates. The main plots were devoted to three surface irrigation methods. Which are 1- Short furrows irrigation (SF) , 2- Long furrows irrigation (LF) and 3- border irrigation, (B) where the sub plots were assigned to the three land leveling methods; traditional, dead leveling (D) (precision land leveling) and ground surface slope of $10 \mathrm{cms} / 100 \mathrm{~m}$ (0.1\% slope) (S).

\section{Parameters studied:}

1. Salt distribution patterns in clay soils:

Soil samples from three soil profiles were collected before planting, after fifth irrigation and after harvesting for each treatment at four depths namely (0-20), (20-40), (40-60) and $(60-80 \mathrm{~cm})$ along the strip and the distance between profiles 10,40 and $70 \mathrm{~m}$, to study the salinity distribution through soil profile at different depths along the strip. 
Table (1): Soil chemical and physical properties of the experimental site.

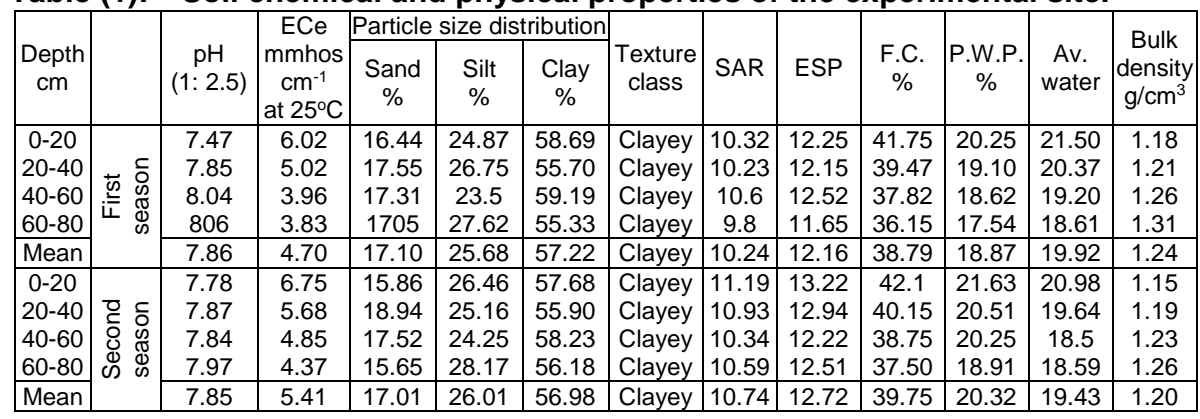

\section{Soil moisture content:}

Soil moisture percentage was determined gravemetrically at three selected sites 10, 40 and $70 \mathrm{~m}$ along the furrow, before irrigation and 2 days after each irrigation and immediately before harvesting. Soil samples were taken with help of auger from the successive soil layers (0-15), (15-30), (30$45)$ and (45-60) cms depth.

\section{Soil moisture extraction patterns:}

Soil moisture extraction patterns were calculated as follows:

$$
\text { S.M.E.P. }=\frac{\text { SME layer }}{\text { Total SME }(\text { seasonal })}
$$

\section{Where:}

SME layer = Season soil moisture extracted water for specific layer.

SME $($ seasonal $)=$ seasonal soil moisture extracted for the whole profiles and calculated according to (Israelsen and Hansen, 1962).

\section{Measurement of water table depth:}

Water table level fluctuation during both growing seasons was monitored by using 18 observation wells that were installed along different treatments. Each observation well was 2.5 meter length and $5 \mathrm{~cm}$ diameter. A metallic sounds fixed in a sealed tapes was used to measure the depth of water table Tables (2 and 3).

Table (2): Average water table level $(\mathrm{cm})$ for the whole season 2004 of cotton crop at different sites along the furrow under different treatments.

\begin{tabular}{|c|c|c|c|c|c|c|c|c|c|}
\hline \multirow{2}{*}{$\begin{array}{c}\text { Irrigation } \\
\text { methods } \\
\text { treatments }\end{array}$} & \multirow{2}{*}{$\begin{array}{c}\text { Land } \\
\text { leveling }\end{array}$} & \multicolumn{3}{|c|}{$\begin{array}{c}\text { Site (1) at } 30 \mathrm{~m} \text { from } \\
\text { furrow inlet }\end{array}$} & \multirow[t]{2}{*}{$\Delta$} & \multicolumn{3}{|c|}{$\begin{array}{c}\text { Site (2) at } 50 \mathrm{~m} \text { from } \\
\text { furrow inlet }\end{array}$} & \multirow[t]{2}{*}{$\Delta$} \\
\hline & & B & A & Mean & & B & A & Mean & \\
\hline \multirow{3}{*}{ Short furrows } & $\bar{T}$ & 104 & 79 & 91.50 & 25 & 105 & 86 & 95.5 & 19 \\
\hline & D & 112 & 85 & 98.50 & 27 & 117 & 92 & 104.5 & 25 \\
\hline & $S$ & 125 & 98 & 111.50 & 27 & 127 & 105 & 116 & 22 \\
\hline \multicolumn{2}{|l|}{ Mean } & 113.67 & 87.33 & 100.50 & 26.34 & 116.33 & 94.33 & 105.33 & 22 \\
\hline \multirow{3}{*}{ Long furrows } & $T$ & 100 & 77 & 88.5 & 23 & 98 & 80 & 89 & 18 \\
\hline & D & 106 & 80 & 93.0 & 26 & 113 & 91 & 102 & 22 \\
\hline & S & 123 & 95 & 109 & 28 & 125 & 100 & 112.5 & 25 \\
\hline \multicolumn{2}{|l|}{ Mean } & 109.67 & 84 & 96.84 & 25.67 & 112 & 90.33 & 101.16 & 21.67 \\
\hline \multirow{3}{*}{ Border } & $T$ & 98 & 75 & 86.5 & 23 & 95 & 73 & 84 & 22 \\
\hline & D & 102 & 83 & 92.5 & 19 & 109 & 89 & 99 & 20 \\
\hline & S & 118 & 90 & 104 & 28 & 120 & 96 & 108 & 24 \\
\hline \multicolumn{2}{|c|}{ Mean } & 106 & 82.67 & 94.33 & 23.33 & 108 & 86 & 97 & 22 \\
\hline
\end{tabular}


Table (3): Average water table level (cm) for the whole season 2005 of cotton crop at different sites along the furrow under different treatments.

\begin{tabular}{|c|c|c|c|c|c|c|c|c|c|}
\hline \multirow{2}{*}{$\begin{array}{l}\text { Irrigation } \\
\text { methods } \\
\text { treatments }\end{array}$} & \multirow{2}{*}{$\begin{array}{c}\text { Land } \\
\text { levelling }\end{array}$} & \multicolumn{3}{|c|}{$\begin{array}{l}\text { Site (1) at } 30 \mathrm{~m} \\
\text { from furrow inlet }\end{array}$} & \multirow[t]{2}{*}{$\Delta$} & \multicolumn{3}{|c|}{$\begin{array}{c}\text { Site (2) at } 50 \mathrm{~m} \text { from furrow } \\
\text { inlet }\end{array}$} & \multirow[t]{2}{*}{$\Delta$} \\
\hline & & $\mathbf{B}$ & A & Mean & & B & A & Mean & \\
\hline \multirow{3}{*}{$\begin{array}{l}\text { Short } \\
\text { furrows }\end{array}$} & $\mathrm{T}$ & 102 & 79 & 90.5 & 23 & 104 & 80 & 92 & 24 \\
\hline & D & 116 & 89 & 102.5 & 27 & 119 & 91 & 105 & 28 \\
\hline & $\mathrm{S}$ & 129 & 98 & 113.5 & 31 & 133 & 101 & 117 & 32 \\
\hline \multicolumn{2}{|c|}{ Mean } & 115.67 & 88.67 & 102.17 & 27 & 118.67 & 90.67 & 104.67 & 28 \\
\hline \multirow{3}{*}{$\begin{array}{l}\text { Long } \\
\text { furrows }\end{array}$} & $\mathrm{T}$ & 99 & 75 & 87 & 24 & 101 & 76 & 88.5 & 25 \\
\hline & D & 110 & 84 & 97 & 26 & 113 & 87 & 100 & 26 \\
\hline & $\mathrm{S}$ & 127 & 96 & 11.5 & 31 & 130 & 99 & 114.5 & 31 \\
\hline \multicolumn{2}{|c|}{ Mean } & 112 & 85 & 98.5 & 27 & 114.47 & 87.33 & 101 & 22 \\
\hline \multirow{3}{*}{ Border } & $\mathrm{T}$ & 95 & 74 & 84.5 & 21 & 97 & 75 & 86 & 22 \\
\hline & D & 106 & 80 & 93.0 & 26 & 109 & 82 & 95.5 & 27 \\
\hline & S & 122 & 93 & 107.5 & 29 & 126 & 96 & 111 & 30 \\
\hline \multicolumn{2}{|c|}{ Mean } & 107.67 & 83.33 & 95.0 & 24.34 & 110.67 & 84.33 & 97.5 & 26.34 \\
\hline
\end{tabular}

\section{RESULTS AND DISCUSSION}

\section{Effect of surface irrigation methods and land leveling practices on:}

1. Salt distribution in soil:

Data presented in Table (4) and Figs. (1-6) clearly show that under all methods of surface irrigation, ECe values were decreased comparing to those obtained before planting. The ECe values after the fifth irrigation were 4.67, 4.78 and $4.25 \mathrm{dSm}^{-1}$ in comparison with before planting which these were 5.25, 5.71 and $5.17 \mathrm{dSm}^{-1}$ under short furrows (SF), long furrows (LF) and border irrigation (B) methods, respectively. As shown in the same table the mean values of ECe were decreased at harvesting of cotton. The results indicate that the decreased in salt content after fifth irrigation were 18.14, 16.33 and $10.98 \%$ under B, LF and SF, respectively. While the decrease in salt content after harvesting of cotton were $21.31,21.00$ and $13.78 \%$ under $B$, LF and SF respectively in the first seasons. For the second season the rate of decrease in salt content after fifth irrigation were 16.96, 14.82 and $10.86 \%$ under B, LF and SF, respectively. Moreover, the decrease in salt content after harvesting of cotton were $18.09,15.63$ and $12.67 \%$ under $\mathrm{B}$, LF and SF respectively.

It is clear from Table (4) that the mean values of salinity distribution were affected by land leveling practices where the lowest mean values under all methods of surface irrigation were recorded under border irrigation method and dead leveling since it was $3.82 \mathrm{dS} / \mathrm{m}^{-1}$ on contrary to this the highest mean value was recorded under long furrow and dead level since the value was $5.17 \mathrm{dS} / \mathrm{m}^{-1}$.

2. Soil moisture extraction patterns by cotton crop as influenced by surface irrigation methods and land leveling:

This parameter might be used as a tool to predict the degree of root distribution within different depths of the effective root zone. 
Values of soil moisture extraction patterns with in the root zone of 60 $\mathrm{cm}$ as affected by surface irrigation method and land leveling in both seasons are recorded in Table (5).

Table (4): Mean values of ECe before planting, after fifth irrigation, after harvesting of cotton and the rate of change under different surface irrigation methods of the two growing seasons.

\begin{tabular}{|c|c|c|c|c|c|c|}
\hline \multirow{2}{*}{$\begin{array}{l}\text { Irrigation } \\
\text { methods }\end{array}$} & \multirow[b]{2}{*}{$\begin{array}{c}\text { Land } \\
\text { leveling }\end{array}$} & \multicolumn{5}{|c|}{$\mathrm{ECe}_{\mathrm{dSm}}{ }^{-1}$} \\
\hline & & $\begin{array}{l}\text { Before } \\
\text { planting }\end{array}$ & $\begin{array}{l}\text { After fifth } \\
\text { irrigation }\end{array}$ & $\begin{array}{c}\text { Rate of } \\
\text { change } \pm \%\end{array}$ & $\begin{array}{c}\text { After } \\
\text { harvesting }\end{array}$ & $\begin{array}{l}\text { Rate of } \\
\text { change }\end{array}$ \\
\hline & & \multicolumn{5}{|c|}{ Season 2004} \\
\hline \multirow{3}{*}{ SF } & $\mathrm{T}$ & 4.98 & 4.30 & -13.65 & 4.25 & -14.66 \\
\hline & D & 6.08 & 5.45 & -10.36 & 5.22 & -14.14 \\
\hline & $\mathrm{S}$ & 4.70 & 4.28 & -8.94 & 4.11 & -12.55 \\
\hline \multicolumn{2}{|c|}{ Mean } & 5.25 & 4.67 & -10.98 & 4.54 & -13.78 \\
\hline \multirow{3}{*}{ LF } & $\mathrm{T}$ & 6.31 & 5.43 & -13.95 & 5.10 & -19.18 \\
\hline & $\mathrm{D}$ & 5.56 & 4.52 & -18.70 & 4.18 & -24.82 \\
\hline & $S$ & 5.26 & 4.40 & -16.35 & 4.26 & -19.01 \\
\hline \multicolumn{2}{|c|}{ Mean } & 5.71 & 4.78 & -16.33 & 4.51 & -21.00 \\
\hline \multirow{3}{*}{ B } & $\mathrm{T}$ & 4.88 & 3.82 & -21.72 & 3.72 & -23.77 \\
\hline & D & 4.57 & 3.71 & -18.82 & 3.58 & -21.66 \\
\hline & $\mathrm{S}$ & 6.05 & 5.21 & -13.88 & 4.93 & -18.51 \\
\hline \multicolumn{2}{|c|}{ Mean } & 5.17 & 4.25 & -18.14 & 4.08 & -21.31 \\
\hline & & \multicolumn{5}{|c|}{ Season 2005} \\
\hline \multirow{3}{*}{ SF } & $\mathrm{T}$ & 5.05 & 4.39 & -13.07 & 4.34 & -14.06 \\
\hline & D & 5.61 & 5.08 & -9.45 & 4.920 & -12.66 \\
\hline & $S$ & 5.76 & 5.18 & -10.07 & 5.11 & -11.28 \\
\hline \multicolumn{2}{|c|}{ Mean } & 5.47 & 4.88 & -10.86 & 4.78 & -12.67 \\
\hline \multirow{3}{*}{ LF } & $\mathrm{T}$ & 4.96 & 4.30 & -13.31 & 4.26 & -14.11 \\
\hline & $\mathrm{D}$ & 6.17 & 5.21 & -15.56 & 5.17 & -16.20 \\
\hline & $S$ & 5.07 & 4.28 & -15.58 & 46.23 & -16.57 \\
\hline \multicolumn{2}{|c|}{ Mean } & 5.40 & 4.59 & -14.82 & 4.55 & -15.63 \\
\hline \multirow{3}{*}{ B } & $T$ & 5.96 & 5.02 & -15.77 & 4.96 & -16.78 \\
\hline & D & 4.66 & 3.88 & -16.67 & 3.82 & -18.03 \\
\hline & $S$ & 5.75 & 4.69 & -18.43 & 4.63 & -19.48 \\
\hline \multicolumn{2}{|c|}{ Mean } & 4.46 & 4.53 & -16.96 & 4.47 & -18.09 \\
\hline
\end{tabular}

Table (5): Soil moisture extracted by cotton roots (\%) for different layers during the two growing seasons.

\begin{tabular}{|c|c|c|c|c|c|c|c|c|c|c|c|c|c|}
\hline \multirow{3}{*}{$\begin{array}{l}\text { Irrigation } \\
\text { methods }\end{array}$} & \multirow{3}{*}{$\begin{array}{l}\text { Land } \\
\text { leveling }\end{array}$} & \multicolumn{6}{|c|}{ Season 2004} & \multicolumn{6}{|c|}{ Season 2005} \\
\hline & & \multicolumn{6}{|c|}{ Soil layers (cm) } & \multicolumn{6}{|c|}{ Soil layers (cm) } \\
\hline & & $0-15$ & $15-30$ & Total & $30-45$ & $45-60$ & Total & $0-15$ & $15-30$ & Total & $30-45$ & $45-60$ & Total \\
\hline \multirow{3}{*}{ SF } & $\bar{T}$ & 4404 & 29.18 & 73.22 & 18.29 & 8.49 & 26.78 & 46.57 & 27.50 & 74.07 & 16.17 & 9.76 & 25.93 \\
\hline & D & 3.45 & 25.46 & 68.91 & 18.93 & 12.16 & 31.09 & 43.95 & 25.17 & 69.12 & 19.11 & 11.77 & 30.88 \\
\hline & & & & & & & & & & & & 13.94 & 59 \\
\hline \multicolumn{2}{|c|}{ Mean } & 43.34 & 27.14 & 70.48 & 18.65 & 10.87 & 29.52 & 44.76 & 25.77 & 70.53 & 17.64 & 11.82 & 29.47 \\
\hline \multirow{3}{*}{ LF } & $\mathrm{T}$ & 45.84 & 26.67 & 72.51 & 18.84 & 8.65 & & 45.25 & 28.46 & 73.74 & 16.65 & 9.64 & 26.29 \\
\hline & D & 43.72 & 27.58 & 71.30 & 19.49 & 9.21 & 28.70 & 44.65 & 24.27 & 68.92 & 18.65 & 12.43 & 31.08 \\
\hline & & 43.22 & 28.49 & 71.71 & 18.81 & 9.48 & 28.29 & 44.10 & 27.60 & 71.70 & 1.35 & 10.95 & 28.30 \\
\hline \multicolumn{2}{|c|}{ Mean } & 44.26 & 27.58 & 71.84 & 19.05 & 9.11 & 28.16 & 44.67 & 26.78 & 71.44 & 17.56 & 11.00 & 28.56 \\
\hline \multirow{3}{*}{ B } & $\mathrm{T}$ & 46.29 & 27.60 & 73.89 & 17.33 & 8.78 & 26.11 & 44.85 & 26.76 & 71.61 & 17.50 & 10.89 & 28.39 \\
\hline & D & 43.32 & 28.21 & 71.53 & 17.69 & 10.78 & 28.47 & 44.15 & 25.17 & 69.32 & 18.50 & 12.08 & 30.58 \\
\hline & S & & 27.33 & & 18.27 & 11.29 & 29.56 & 42.65 & 25.75 & 68.41 & 18.83 & 12.77 & 31.60 \\
\hline \multicolumn{2}{|c|}{ Mean } & 44.24 & 27.71 & 71.95 & 17.76 & 10.28 & 28.05 & 43.88 & 25.89 & 69.77 & 48.27 & 11.96 & 30.23 \\
\hline
\end{tabular}


Sonbol, H. A. et al.
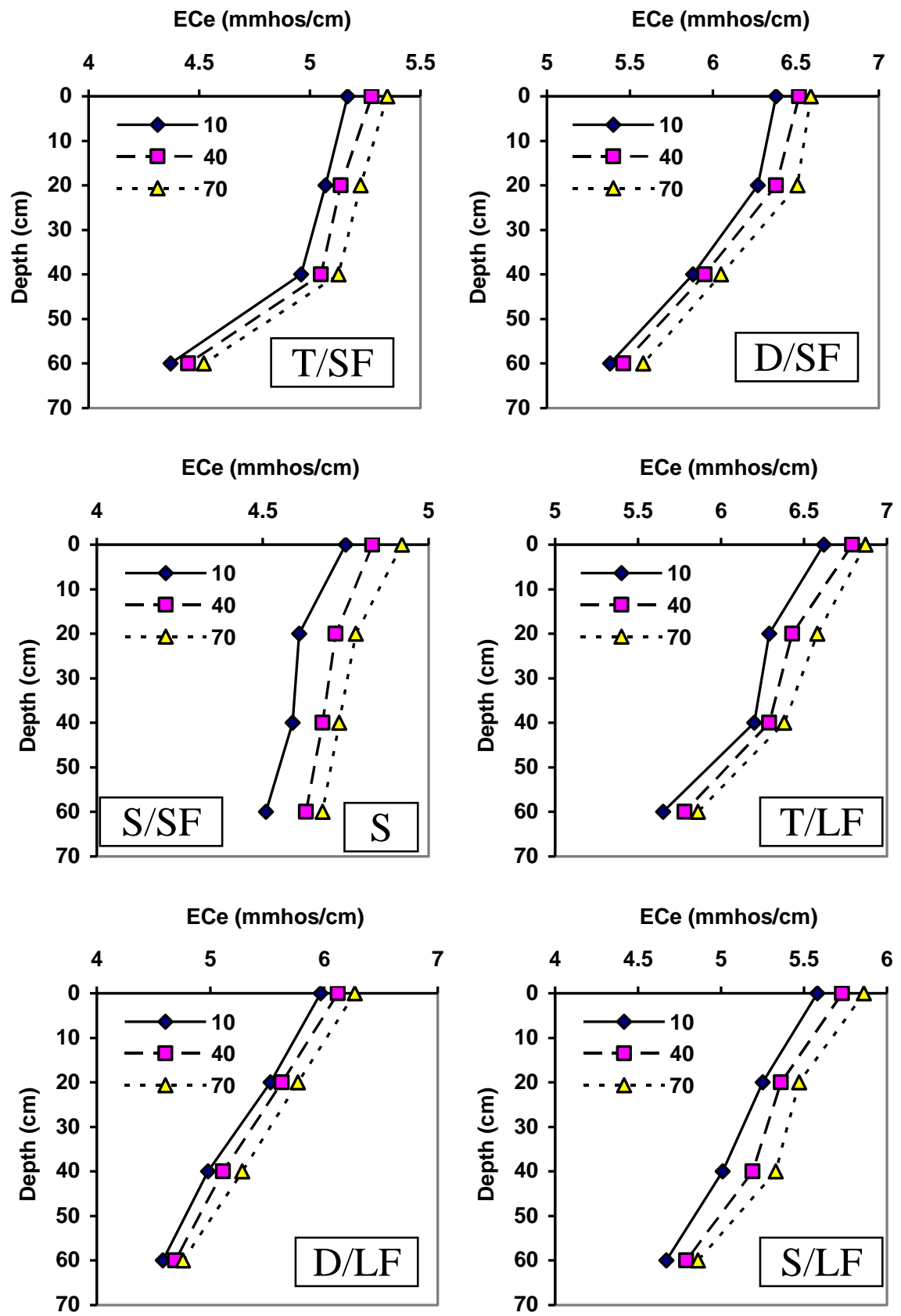

Fig. (1) Salt distribution in soil profile for traditional, dead and slope land leveling under short furrows, long furrows and border irrigation before planting in the first season. 

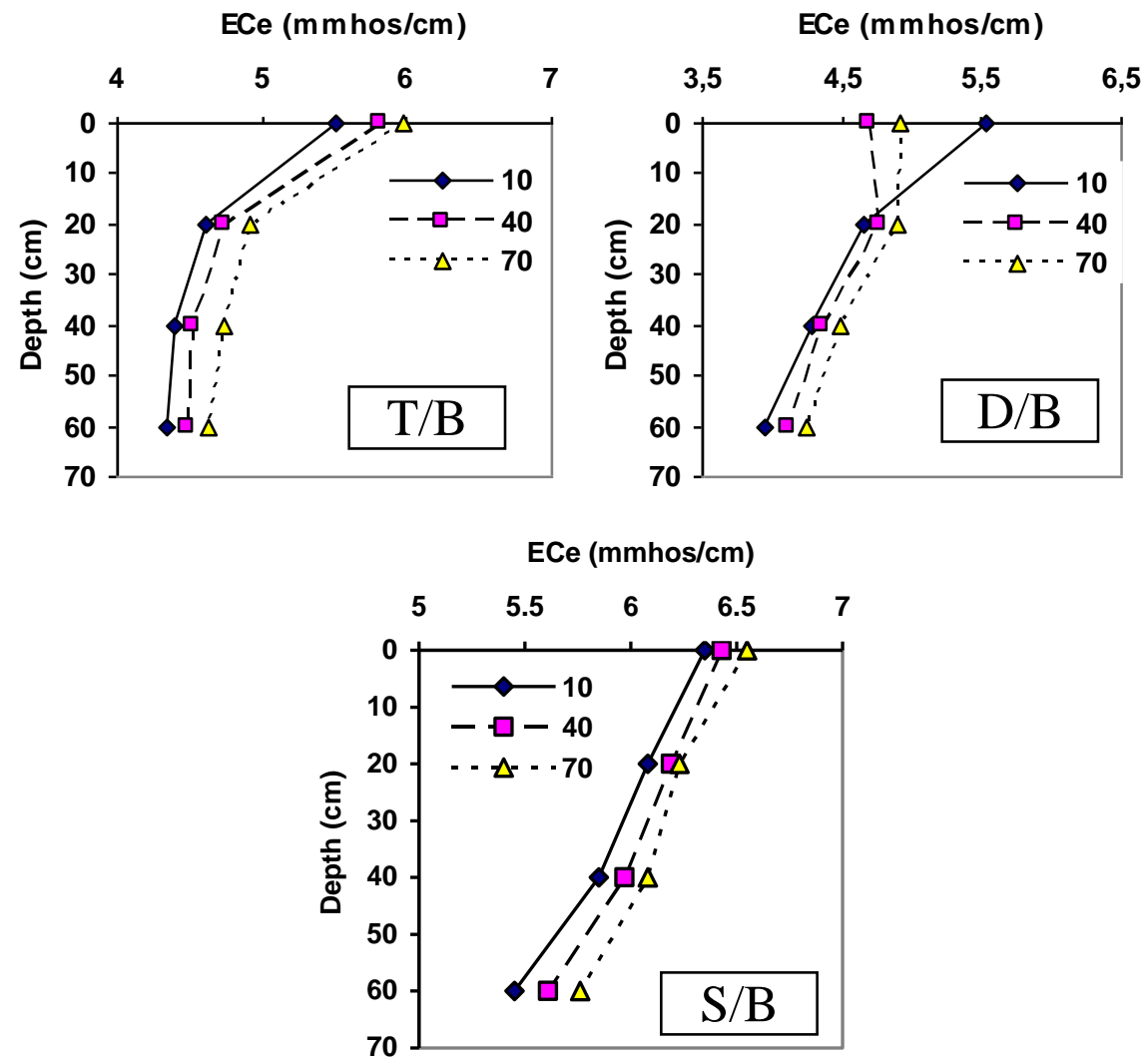

Fig. (1): Cont.
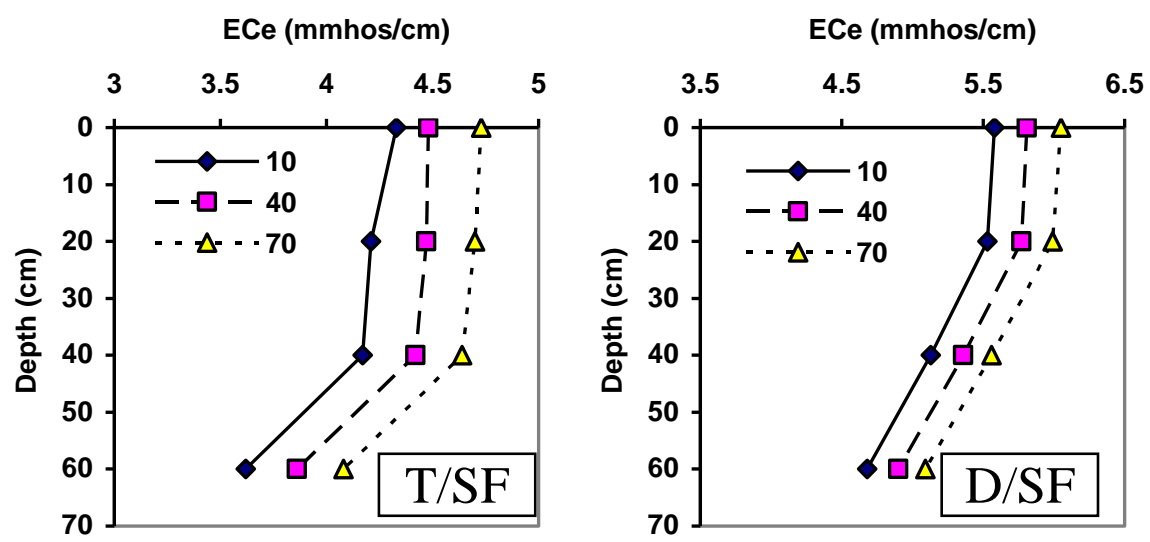

Fig. (2) Salt distribution in soil profile for traditional, dead and slope land leveling under short furrows after fifth irrigation, long furrows and border irrigation before planting in the first season. 
Sonbol, H. A. et al.
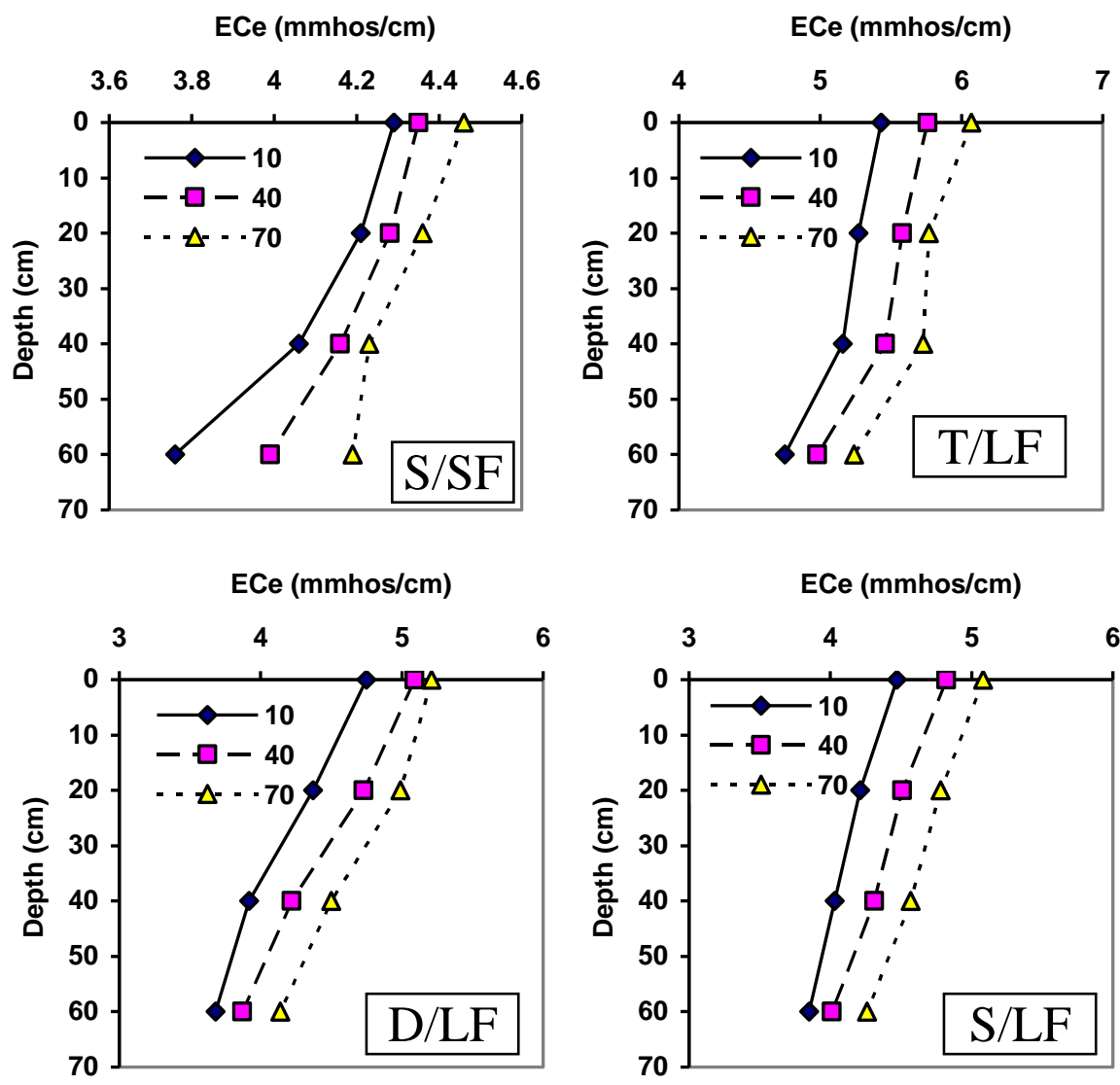

$\mathrm{ECe}(\mathrm{mmhos} / \mathrm{cm})$

$\mathrm{ECe}$ (mmhos/cm)
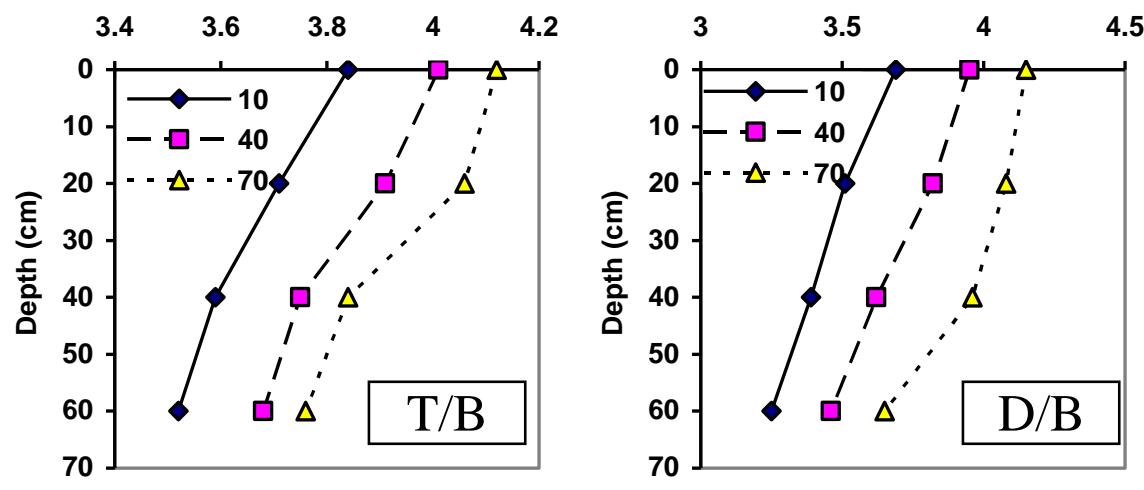

Fig. (2): Cont. 


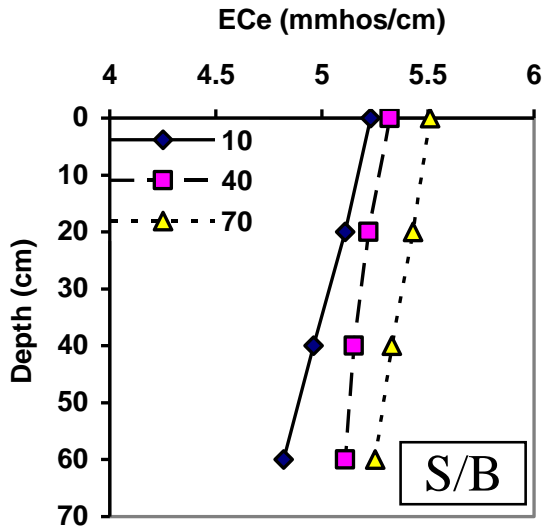

\section{T/LF}

Fig. (2): Cont.

$\mathrm{ECe}(\mathrm{mmhos} / \mathrm{cm})$

$\mathrm{ECe}(\mathrm{mmhos} / \mathrm{cm})$
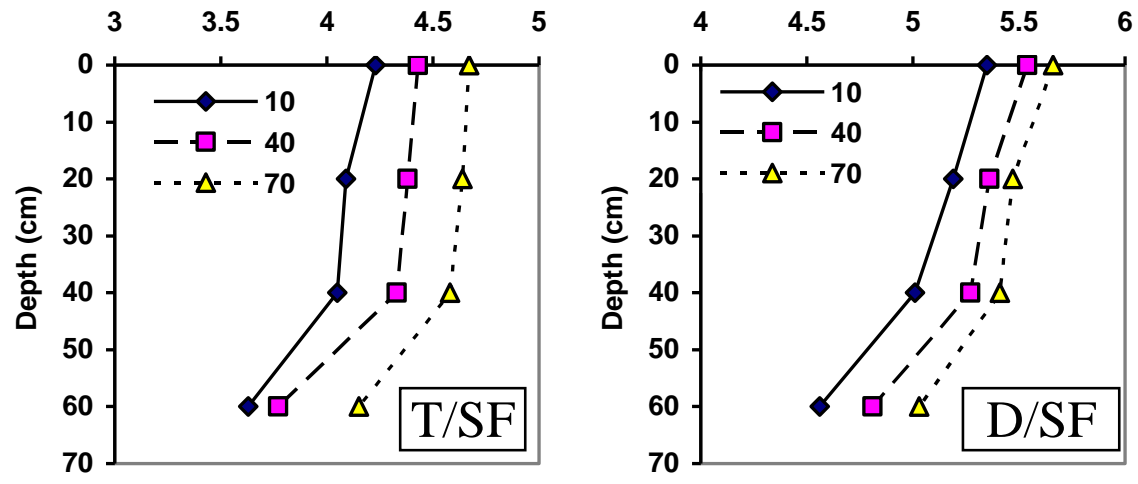

$\mathrm{ECe}(\mathrm{mmhos} / \mathrm{cm})$

$\mathrm{ECe}(\mathrm{mmhos} / \mathrm{cm})$
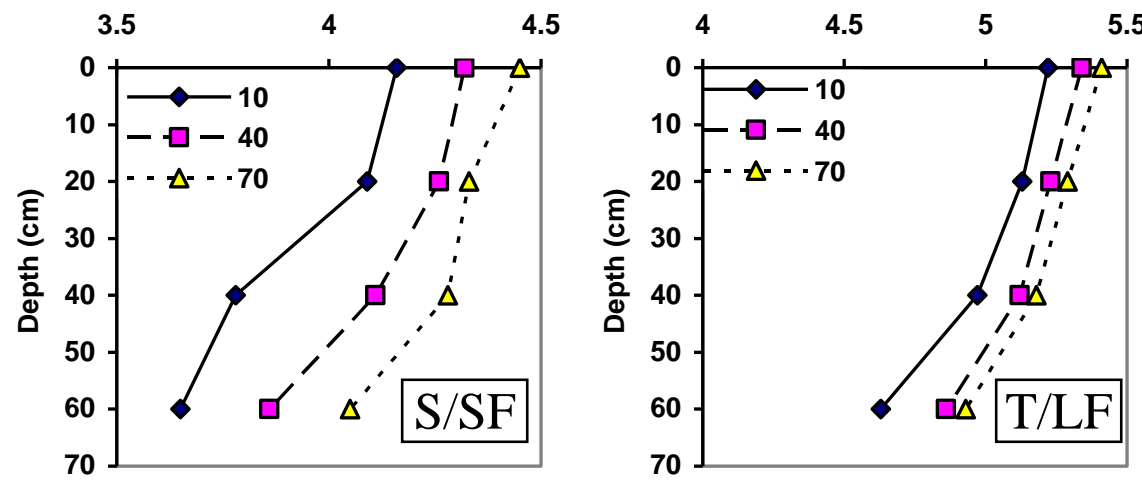

Fig. (3) Salt distribution in soil profile for traditional, dead and slope land leveling under short furrows, long furrows and border irrigation after harvesting of cotton in the first season. 
Sonbol, H. A. et al.
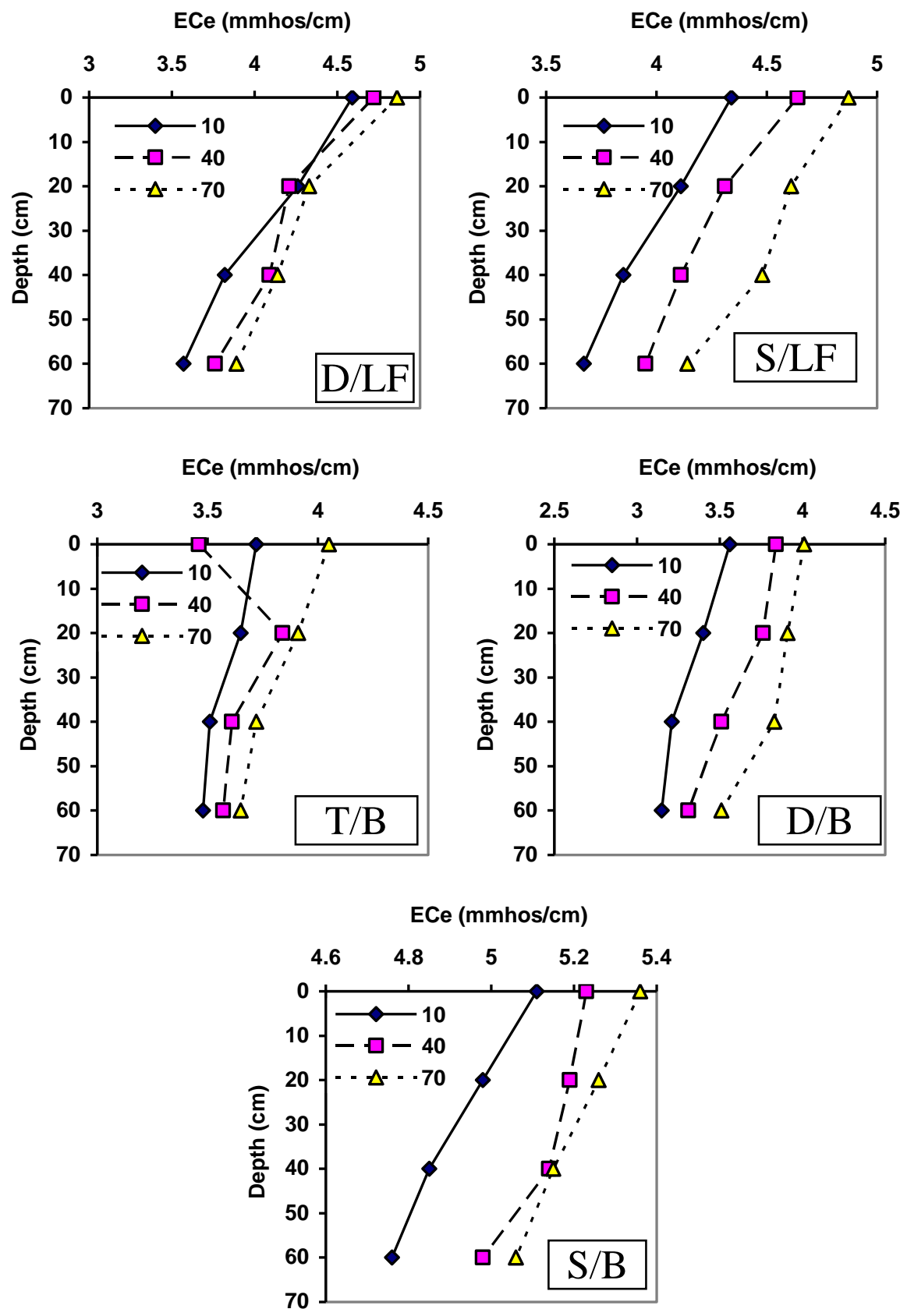

Fig. (3): Cont. 

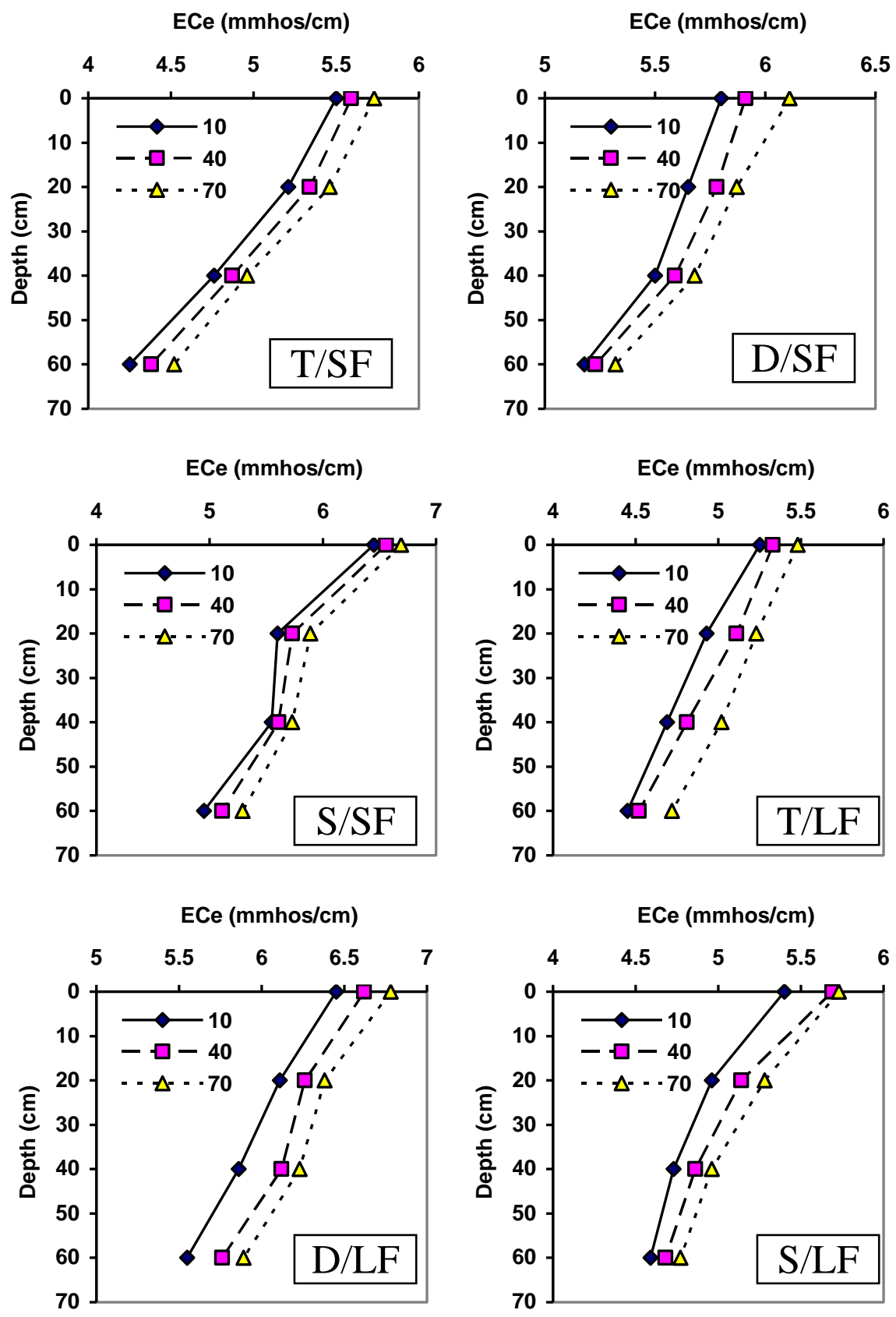

Fig. (4) Salt distribution in soil profile for traditional, dead and slope land leveling under short furrows, long furrows, and border irrigation before planting in the second season. 
Sonbol, H. A. et al.
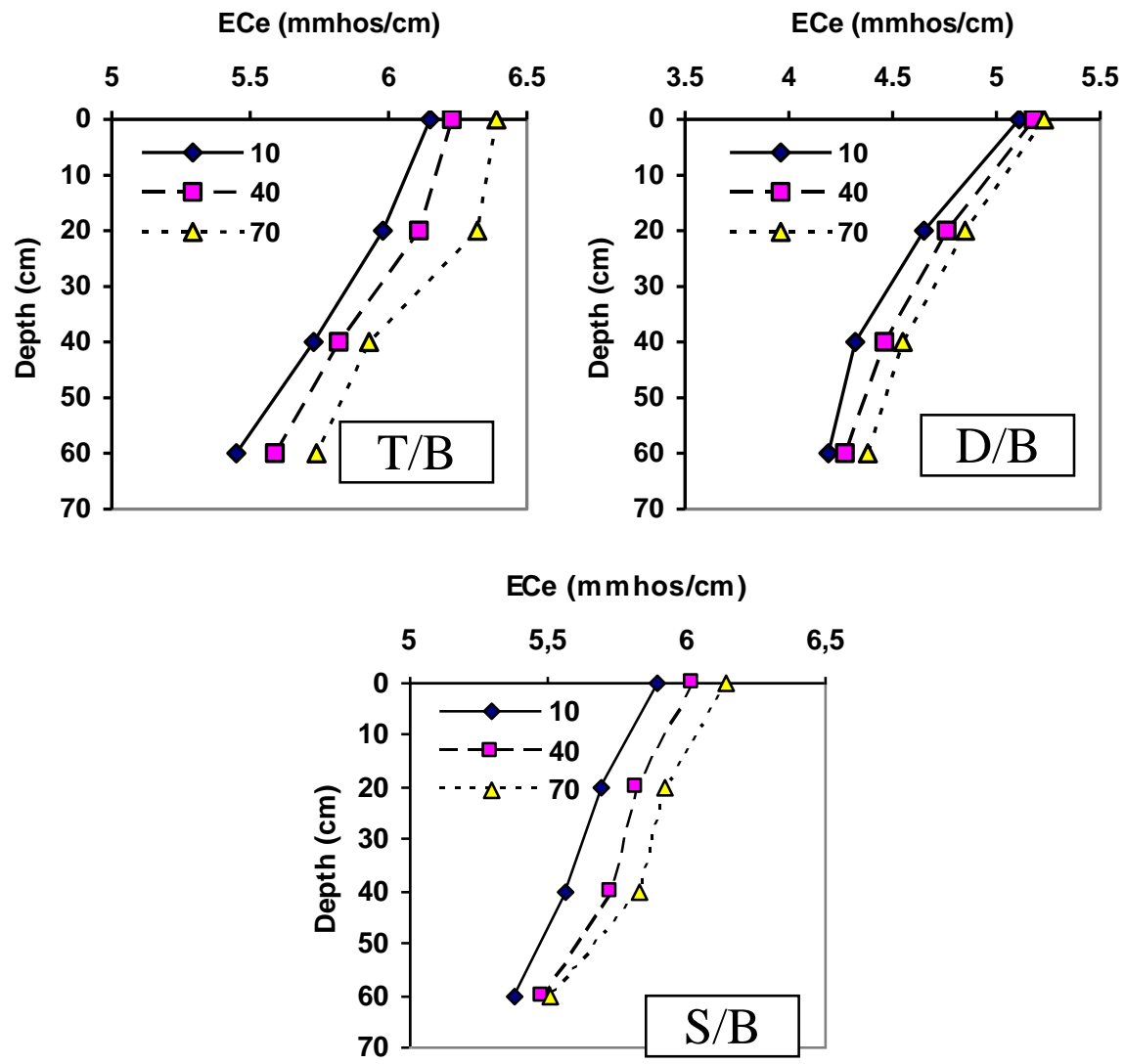

Fig. (4): Cont.
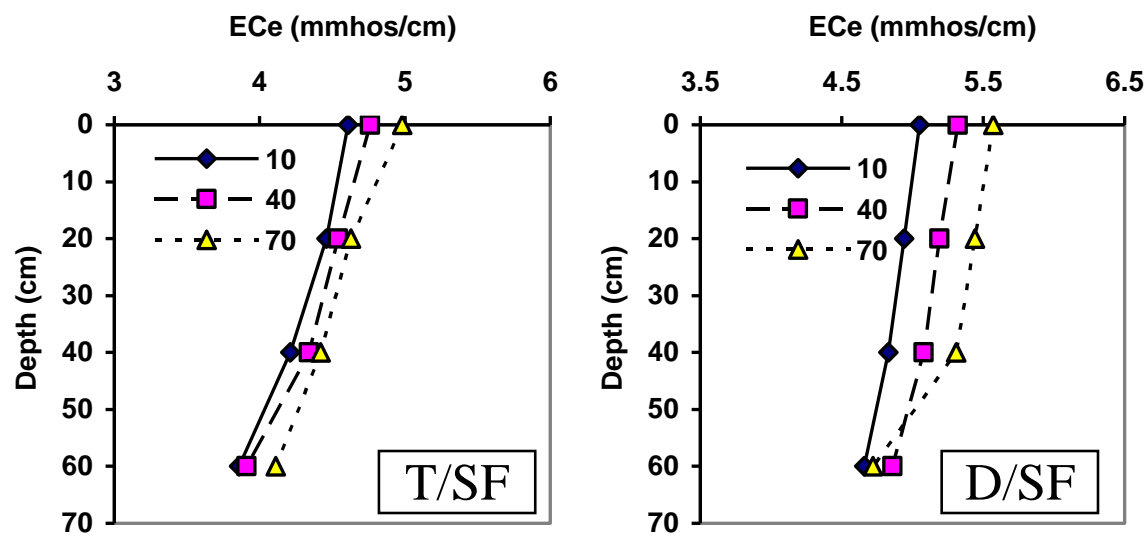

Fig. (5) Salt distribution in soil profile for traditional, dead and slope land leveling under short furrows, long furrows, and border irrigation after fifth irrigation in the second season.

8010 

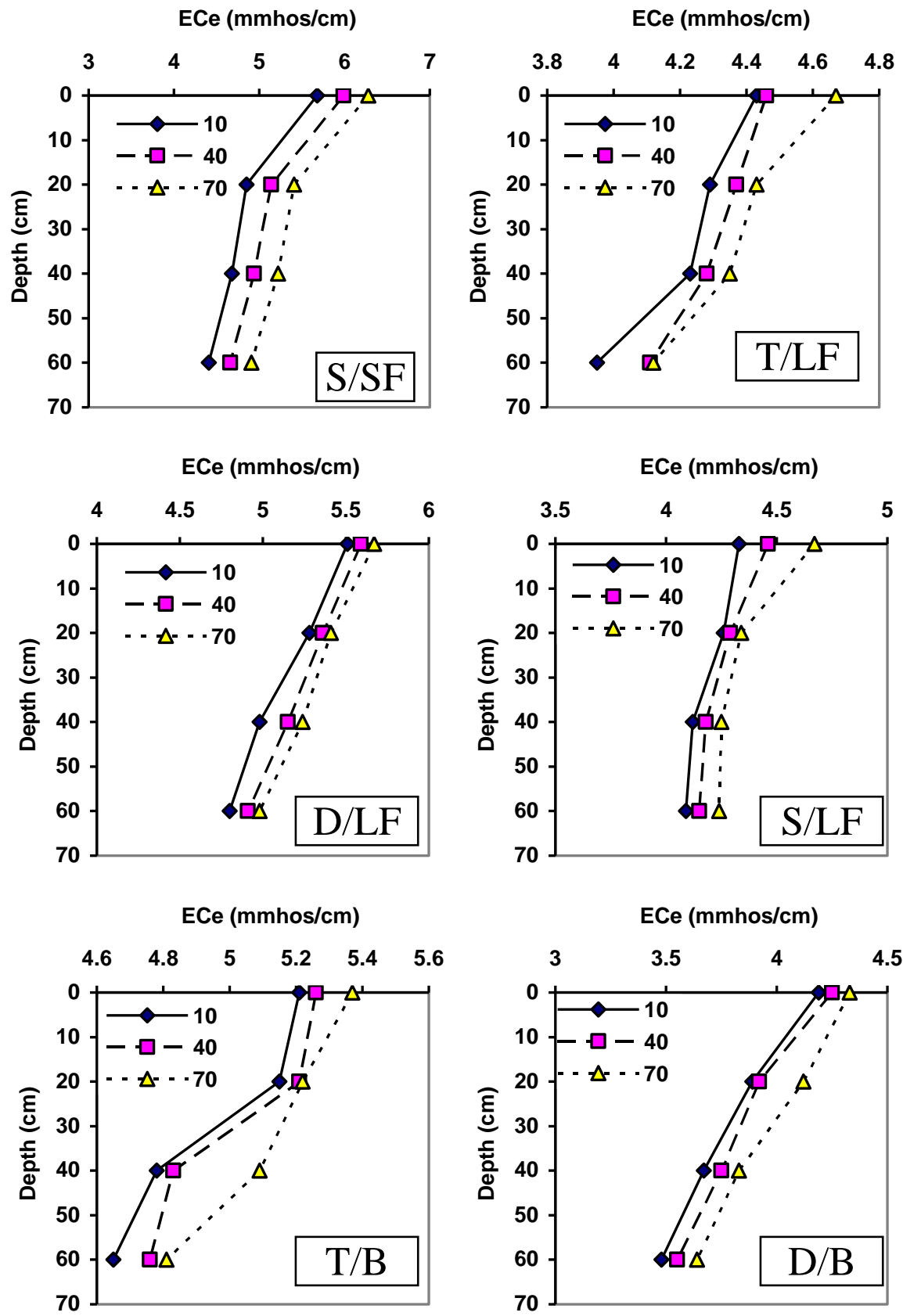

Fig. (5): Cont. 
Sonbol, H. A. et al.

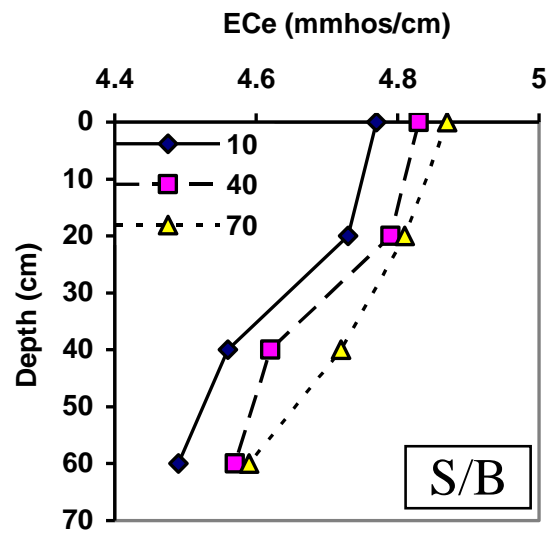

Fig. (5): Cont.
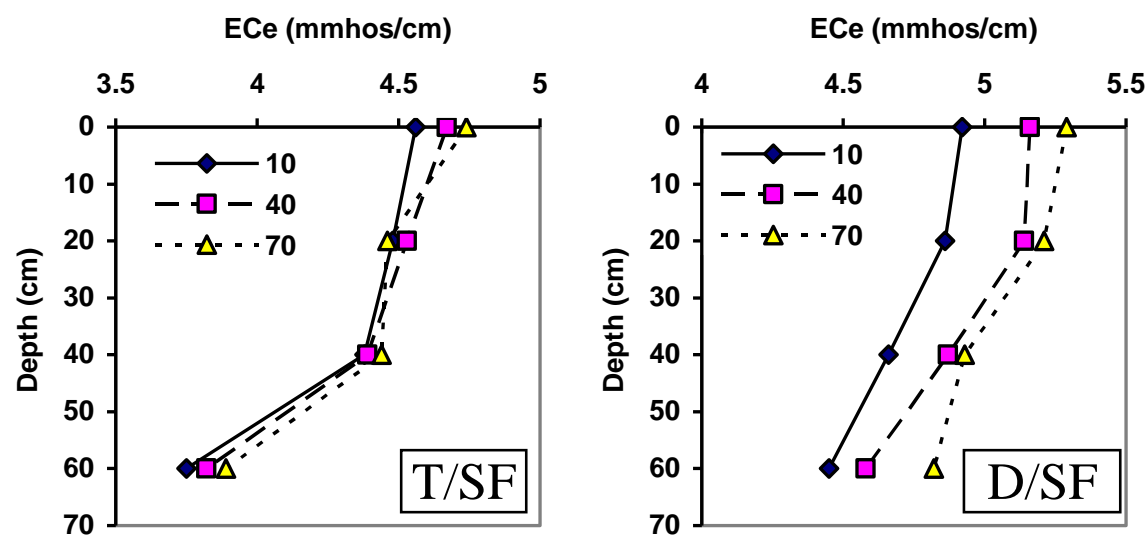

$\mathrm{ECe}$ (mmhos/cm)

$\mathrm{ECe}(\mathrm{mmhos} / \mathrm{cm})$
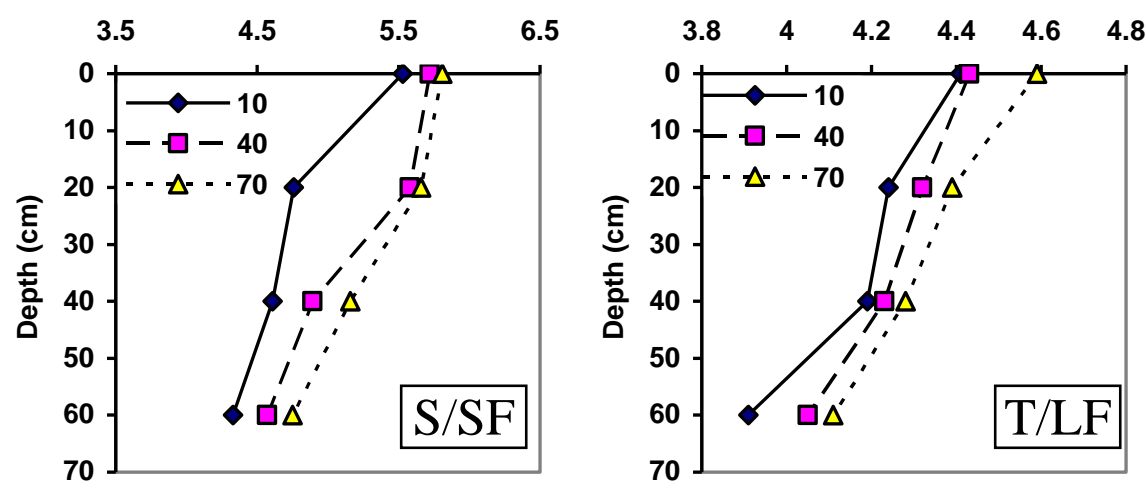

Fig. (6) Salt distribution in soil profile for traditional, dead and slope land leveling under short furrows, long furrows and border irrigation after harvesting of cotton in the second season. 
J. Agric. Sci. Mansoura Univ., 32 (9), September, 2007
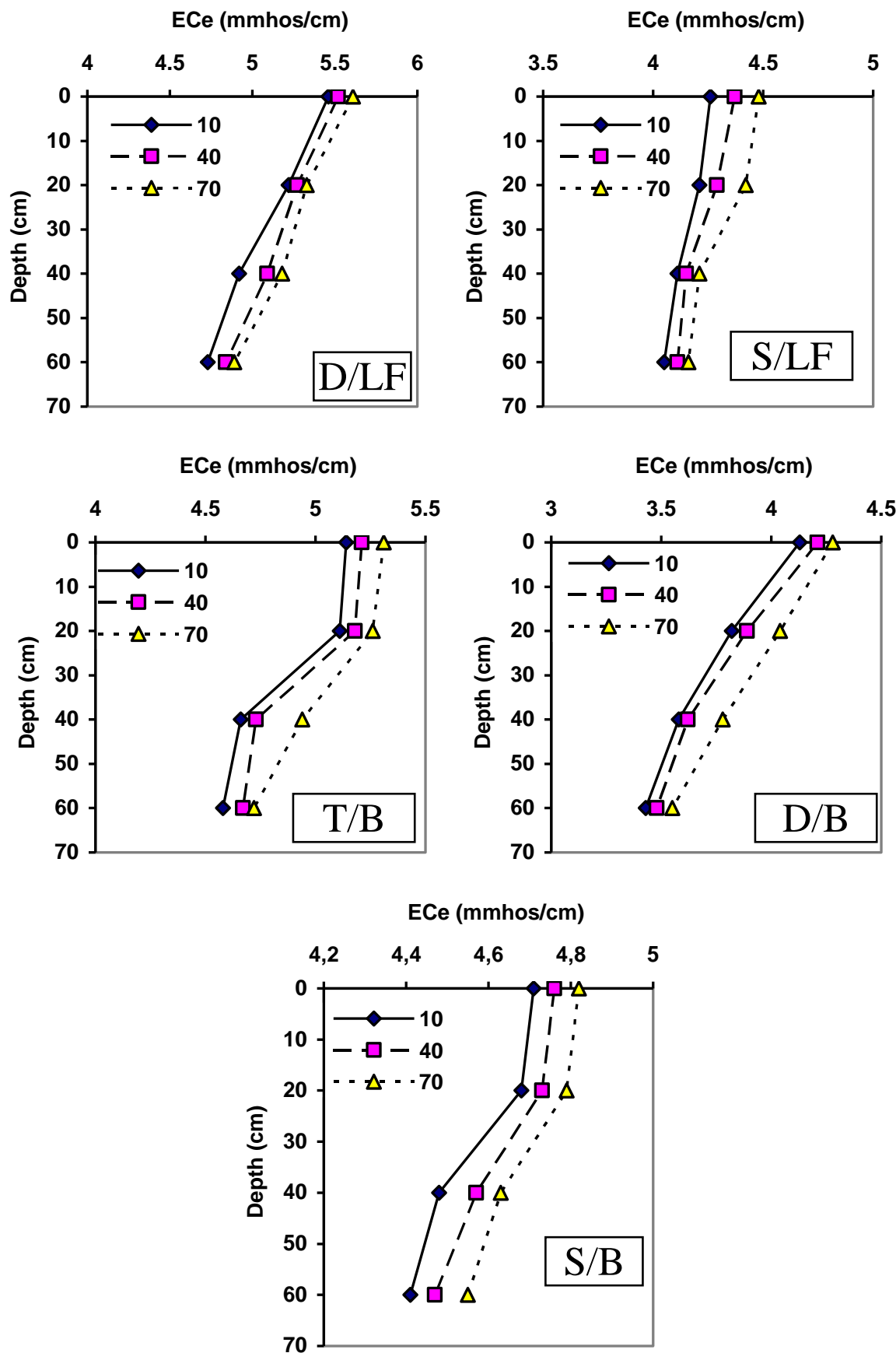

Fig. (6): Cont.

8013 
In both seasons results clearly indicate that the most of the water consumed by plants was removed from the surface layer $(0-15 \mathrm{~cm})$ and $(15-$ $30 \mathrm{~cm}$ ) while less water was extracted from the sequences layers. Average values o soil moisture extraction pattern from the soil layer $(0-30 \mathrm{~cm})$ in the first season were $73.22,68.91$ and $69.31 \%$ for $T, D$ and $S$, respectively under SF while the corresponding values under long furrows were $72.51,71.30$ and $71.71 \%$. Also, under border irrigation the values were found to be 73.89 , 71.53 and $70.44 \%$ for $T, D$ and S, respectively. It was observed that the highest uptake of water by cotton plants was occurred with traditional land leveling under border irrigation method for both seasons. On the other hand, the lowest uptake of water was obtained with $0.1 \%$ ground surface slope under short furrows irrigation. It can be concluded that, more than $70 \%$ of the water extracted by cotton roots was obtained for the upper $30 \mathrm{~cm}$ soil layer and less than $30 \%$ form the lower depth $(30-60 \mathrm{~cm})$.

\section{REFERENCES}

Abd El-Razek, A.A.; A.A. Wahdan; E.E. Kaoud and A.M. Abd El-Shafi (1992). Soil moisture and salt distribution patterns in clay soils as affected by different irrigation systems. Egypt. J. Soil Sci., 32, No. 3, pp. 343-360.

Abo Soliman, M.S.M.; S.M. El-Barbary; L. Bengamen and M.M. Saied (1996). Some aspects of soil management techniques at North Delta. Egypt. J. Appl. Sci., (3): 245-252.

Black, C.A. (1965). Methods of soil analysis. Amer. Soc Agron. Inc., Madison, Wisconsin, U.S.A.

Dewis, J. and F. Fertias (1970). "Physical and chemical methods of soil and water analysis.: Soils Buletin NO. 10 FAO. Rome.

El-Mowelhi, N.M.; H.A. Shams El-Din; M.A. Abo El-Soud and M.M. Saied (1999). Water management for improving irrigation efficiencies at North Delta. Third conference of on Farm Irrigation and Agroclimatology. Jan. 25-27, 1999, Dokki, Egypt. p. 37-52.

El-Mowelhi, N.M.; M.S.M. Abo Soliman; S.A. Abd El-Hafez and E.A. Gazia (1995). On-farm water management in soils of Kafr El-Sheikh, Evaluation of land leveling practices. Jan. 2-4, 1995, Dokki, Egypt. pp. 174-185. Second Conference of On Farm Irrigation and Agroclimatology.

El-Shahawy, M.I. (2004). Same aspects of water management in furrow irrigation under cotton crop. J. Agric. Sci Mansoura Univ., 29(6): 36513660.

Helmy, M.A.; S.M. Gomaa; E.M. Khalifa and A.M. Helal (2000). Production of corn and sunflower under conditions of drip and furrow irrigation with reuse of agricultural drainage water. Misr J. Ag. Eng., 17(1): 125-147.

Hessse, P.R. (1971). "A text Book of soil chemical analysis". Juan Murry (Publisher) Ltd., London.

Israelsen, O.W. and V.E. Hansen (1962). Flow of water into and through soils irrigation principles and practices, $3^{\text {rd }}$ Edition, John Wiley and Sons, Inc., New York, N.Y., U.S.A. 
Jackson, M.L. (1967). "Soil Chemical Analysis" Prentice-Hall of India, New Delhi.,

Meleha, M.E. (2000). Effect of furrow length and methods of applying irrigation on cotton yield and water use efficiency. J. Agric. Sci. Mansoura Univ., 25(3): 1883-1890.

Richards, L.A. (1954). "Diagnosis and improving of saline and Alkaline soils". U.S., Salinity Laboratory Staff. Agric. Handbook, No. 60.

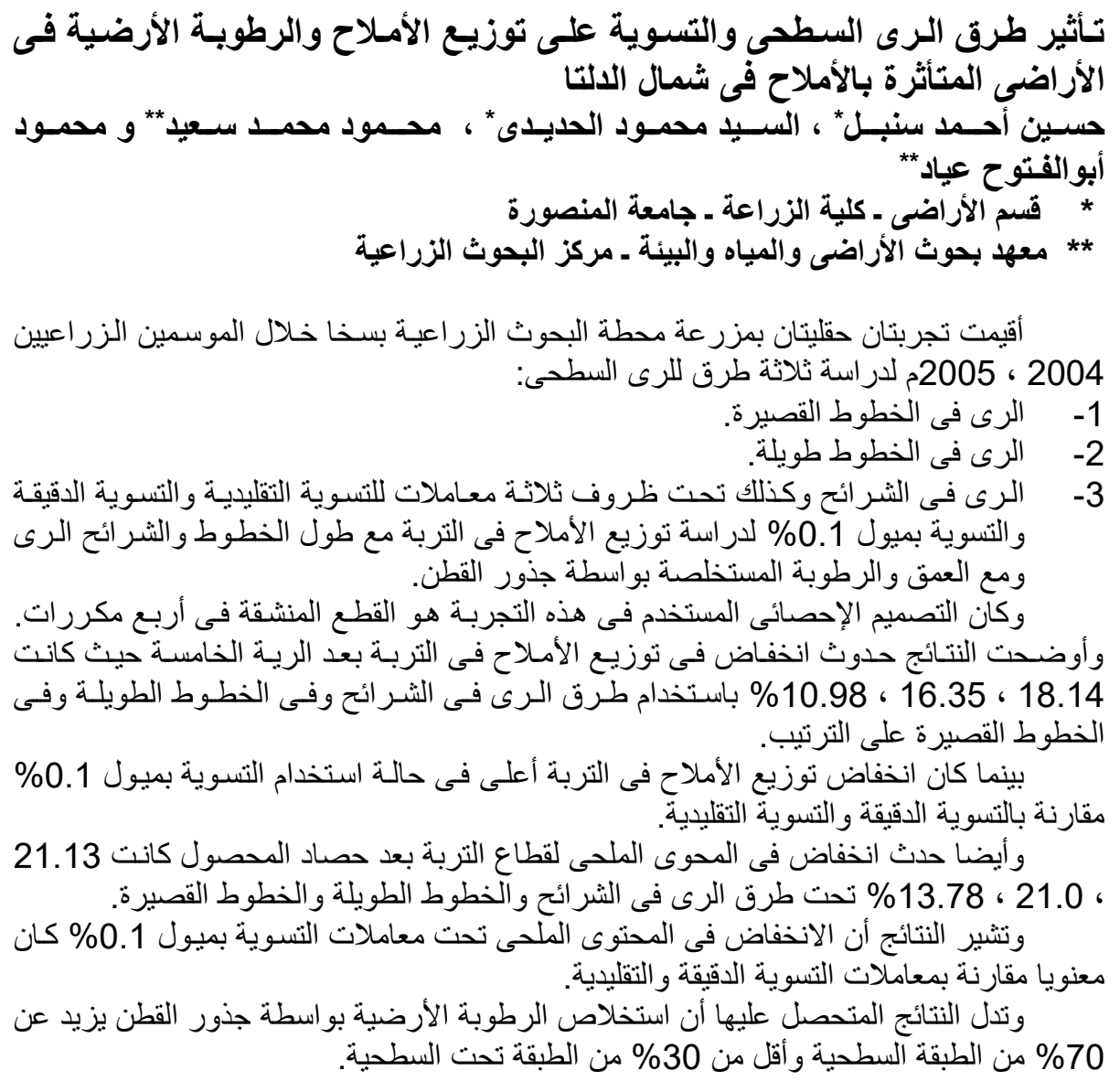

